\title{
Tax Seminar I on Relevant Issues Related to the Permanent Establishment in the Light of the OECD Model Tax Convention on Income and Capital
}

\author{
Filip Djambov, Martijn Veltrop \& Li Shao Wu
}

\section{Introduction}

A tax seminar for students following the LL.M course in International and European Tax Law was held at the Faculty of Arts and Social Sciences of Maastricht University on 11 December, 2013. The objective of this seminar was to provide the students with additional information and insights on the permanent establishment (PE) concept in preparation for their upcoming exam and, at the same time, give them a deeper understanding of the current developments in this area. Dr Marcel Schaper, assistant professor of law at Maastricht University, welcomed the speakers as well as the participating students and gave a brief introduction to the subject of the seminar. The seminar featured two presentations given by Mr Andreas Perdelwitz, principal research associate in the International Bureau of Fiscal Documentation (IBFD) European Knowledge Group, and Ms Oana Popa, senior research associate in the IBFD.

If an enterprise of one state has a permanent establishment in another state, international tax law allocates the taxing rights on the profits of the enterprise made through that PE to that other state. According to article 5 of the OECD Model Tax Convention ${ }^{1}$ any fixed place of business can qualify as a PE if it is at the disposal of the enterprise. Furthermore, the place should not only be fixed geographically, but also have a certain degree of permanence in time. Finally, a business should be carried on through that place. During the first presentation, $\mathrm{Mr}$ Perdelwitz focussed specifically on the 'certain degree of permanence' condition and in the second presentation Ms Popa discussed the 'at the disposal of' criterion.

1 OECD Model Tax Convention on Income and Capital 2010. 


\section{A Certain Degree of Permanence: Between Temporary and Everlasting Business Activities}

According to Mr Perdelwitz, the key element that a PE should have a 'certain degree of permanence' is not a clear cut notion. The criterion is interpreted in very diverging ways, which was demonstrated by $\mathrm{Mr}$ Perdelwitz by referring to two similar cases with very different outcomes. In the first case, the Supreme Court of Norway decided that the presence in Ivory Coast for duration of 66 days was not enough to constitute a $\mathrm{PE}_{1}{ }^{2}$ while in the second case, the Indian court, ${ }^{3}$ decided that a presence of 64 days is sufficiently permanent for a PE to exist.

In 2003, the OECD introduced a six month rule of thumb in the Commentary. ${ }^{4} \mathrm{Mr}$ Perdelwitz argued that this rule is not a universal one due to the fact that the degree of permanence can also depend on the nature of the business. He expressly mentioned the following two exceptions.

The first exception applies to recurrent activities that extend over several years. In such cases, the underlying idea is to take into account the combination between the duration of the recurrent activity in each year and the number of years that this activity is carried out at that same place. This point was illustrated by the Fowler case in which an American salesman carried out activities at a Canadian fair for three weeks each year. ${ }^{5}$ The OECD describes a similar situation in its Discussion Draft of October 2011. ${ }^{6}$ In that situation, a trader rented a stand at a commercial fair for 15 consecutive years for a period of five weeks each year. Corresponding to the judgment of the Canadian court in the Fowler case, the OECD advises that the time requirement for a PE

2 Supreme Court, decision of 8 June 2004 in PGS Geophysical AS, No. 2004-01003-A.

3 Income Tax Appellate Tribunal, decision of 29 August 2008 in Fugro Engineering BV, No. IT Appeal NOS. 269 and 1754 (Delhi) of 2007 (122 TTJ 655).

4 Commentary on article 5, par 6 of the OECD Model Tax Convention on Income and Capital 2010.

5 Tax Court of Canada, decision of 8 August 1990 in Fowler, 90 D.T.C. 1834.

6 OECD Discussion Draft of October 2011 on article 5 of the Model Tax Convention. 
is met due to the recurring nature of the activity, regardless of the fact that any consecutive presence lasts less than six months in each year. Mr Perdelwitz noted that paragraph 6.3 of the OECD Commentary on article 5 of the OECD Model Tax Convention implies that the trader would retroactively have a PE in such circumstances. However, whether actual taxation takes place also depends on the domestic legislation of the state concerned, such as the statute of limitations. In addition, in the Revised Discussion Draft of October $2012^{7}$ the OECD takes into account the specific nature of the relevant business. However according to Mr Perdelwitz, the Discussion Drafts of 2011 and 2012 leave open issues such as what is the overall reference period and what is the minimum period per occurrence?

The second exception applies to one-off projects. In such cases, the activities constitute a business which is carried on exclusively in the source state. Mr Perdelwitz explained that the business may be of a short duration because of its nature, but the important fact is the strong connection with that state. The Revised OECD Discussion Draft of October 2012 provides an example of a sole proprietor who, for a period of four months, carries out catering services in the source state. Because this is a self-contained activity which is the only business activity carried out by the proprietor, this is considered to be a one-off project. However, this is not the case when a company permanently carries on a business in the Resident State and only temporarily operates a catering facility for a sports event in the Source State. Mr Perdelwitz questioned whether it is fair that the same activity is treated differently based on who carries it out, but left the question open to future discussion.

\section{At the Disposal Of: The Way towards a Broader Concept?}

Ms Popa first discussed the relevance of the concept of 'at the disposal of (the disposal concept). She stated that, even though it is not expressly mentioned in article 5 of the Model Tax Convention, the disposal concept is one of the conditions for a PE to exist. She furthermore noted that every situation should be evaluated on the basis of the facts at hand in order to determine whether a place is at the disposal of an enterprise.

7 Revised OECD Discussion Draft of October 2012 on article 5 of the OECD Model Tax Convention. 
Before the disposal concept was introduced in 1977, a place constituted a PE if it was used for the business. After the concept had been adopted in the Commentary, the OECD took the position that there was no benefit of defining the concept. Another issue was the impossibility to formulate an abstract definition. However, Ms Popa mentioned that the $\mathrm{BIAC}^{8}$ has send several letters to the OECD stating that more clarity on the disposal concept was required. In its subsequent Discussion Drafts, the OECD acknowledged that the disposal concept should be clarified and discarding the concept would create various problems.

The OECD elaborated on four examples in order to clarify the disposal concept. These examples are criticized for not providing a clear guideline on the interpretation of the disposal concept. Ms Popa noted that the examples raise more questions than answers.

Ms Popa shared her observations on the OECD examples with the students. The first example concerns a salesman who regularly visits a major client in the office of his client. ${ }^{9}$ The office of the client is not deemed to be at the disposal of the salesman. Ms Popa argued that the salesman does not have any control over the office and that the mere presence of the salesman is not enough for the client's office to constitute a PE.

The second example describes an employee of a parent company who is allowed to use an office in the headquarters of the subsidiary. ${ }^{10}$ The OECD considers the office to be at the disposal of the employee, and as such at the disposal of the parent company. Ms Popa noted that the OECD implies an element of control and indicated that the employee is present at the office and that he may use the office.

The third example was about a road transportation enterprise using a delivery dock. ${ }^{11}$ According to the OECD, the delivery dock is not at the disposal of the enterprise because of its limited presence there. Ms Popa expressed her doubts in what way the limited presence is relevant for the disposal concept. On the other hand, she noted that it is possible that the activity at the delivery dock is merely an auxiliary one and therefore it will not be considered as a PE.

8 Business and Industry Advisory Committee.

9 Paragraph 4.2 of the Commentary on article 5 of the OECD Model Tax Convention.

10 Paragraph 4.3 of the Commentary on article 5 of the OECD Model Tax Convention.

11 Paragraph 4.4 of the Commentary on article 5 of the OECD Model Tax Convention. 
The final example is the much debated painter case. ${ }^{12}$ According to the OECD, the painter has the building at his disposal, even though it is not clear whether the painter has any control. According to Ms Popa, many authors disagree with the example due to the contradictions it raises. The painter example suggests that a service provider who goes to the premises of the client to perform his business would immediately have a place at his disposal.

Besides the examples provided by the OECD, Ms Popa also researched the case law of several jurisdictions in order to determine how the different countries look at the disposal concept. Based on her research, she developed the following scale:

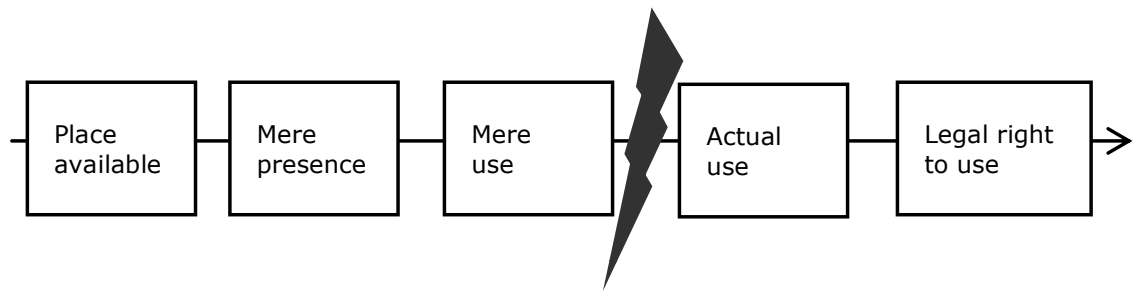

As a result of her research, Ms Popa drew the dividing line between having a place of business at the disposal of between 'mere use' and 'actual use'. The difference lays in the element of factual or legal control. Some examples for identifying control are the unrestricted access to the premises; not being removed without consent; who is giving instructions; and who pays for the maintenance and rent. The other element to the optimal disposal concept is the activities of the foreign entity carried out at such premises, i.e. the degree of identification of the premises with the foreign entity.

\section{Concluding remarks}

On a personal note, the authors agree that the tax seminar has been valuable in preparation for the exam. Furthermore, the information provided by the speakers has given us new insights and a better understanding of the permanent establishment concept in general.

12 Paragraph 4.5 of the Commentary on article 5 of the OECD Model Tax Convention. 